\title{
Phage Therapy: Consider the Past, Embrace the Future
}

\author{
Junwei Wei ${ }^{1}\left[\right.$, Nan Peng ${ }^{1}$, Yunxiang Liang ${ }^{1}$, Keke $\mathrm{Li}^{2}$ and Yingjun $\mathrm{Li}^{1, *}$ \\ 1 State Key Laboratory of Agricultural Microbiology, College of Life Science and Technology, \\ Huazhong Agricultural University, Wuhan 430070, China; weijw@webmail.hzau.edu.cn (J.W.); \\ nanp@mail.hzau.edu.cn (N.P.); fa-lyx@163.com (Y.L.) \\ 2 Henan Jinbaihe Biotechnology Co., Ltd., Tangyin, Anyang 455000, China; jbhlkk@jbh2013.com \\ * Correspondence: yingjun@mail.hzau.edu.cn; Tel.: +86-2787281267; Fax: +86-2787280670
}

Received: 20 September 2020; Accepted: 20 October 2020; Published: 29 October 2020

\begin{abstract}
Antibiotic-resistant bacteria infections pose a threat to public health. Considering the difficulty in developing new antibiotics, it is an urgent need to develop alternative therapies against bacterial pathogens. Bacteriophages (phages) are evaluated as potential substitutes or adjuncts of antibiotics because they are abundant in nature and could specifically lyse bacteria. In this review, we briefly introduce phage therapy and its advantages compared with traditional antibiotic therapy. We also summarize new emerging phage technologies, such as CRISPR-Cas, synthetic phages, etc., and discuss some possible obstacles and potential risks in the application process. We believe that, with the advancement in synthetic biology and delivery technology, phage therapy has broad prospects in the future.
\end{abstract}

Keywords: antibiotic resistance; phage therapy; CRISPR-Cas; phage engineering; Phage-antibiotic synergy

\section{Introduction}

Since Frederick W. Twort and Félix d'Hérelle discovered bacteriophages in 1915, they have become a research hotspot as a natural antimicrobial agent. Félix d'Hérelle attempted to treat dysentery with phage in 1919 [1]. However, due to the discovery and application of broad-spectrum antibiotics in the 1940s, diseases caused by bacterial infections can be effectively treated, and the morbidity and mortality rates have dropped significantly; therefore, the phage therapy was quickly dwarfed [2]. Eastern Europe became the only region in the world that viewed phage therapy as an alternative to antibiotics. Among them, Poland and the Soviet Republic (particularly the Georgia and Russia Soviet Socialist Republic) have made significant contributions to the development of phage therapy because of their insistence [3].

In the war against pathogenic bacteria, antibiotics have always been an important weapon in human hands. The discovery and use of antibiotics have made great contributions to modern medicine. However, a series of problems have become increasingly serious with the extensive use even abuse of antibiotics. First, the massive use of antibiotics leads to bacterial resistance mutations. With the continuous accumulation and spread of bacterial resistance, some pathogens have become superbugs since no antibiotics can fight against them [4]. According to the "Antibiotic Resistance Threats In The United States" reported by the US Centers for Disease Control and Prevention in 2019, more than 2.8 million cases of drug-resistant bacterial infections occur in the United States each year, resulting in more than 35,000 deaths. In addition, due to the broad-spectrum and high-efficiency killing ability of antibiotics, antibiotic therapy is often accompanied by the risk of harming human health. For example, antibiotics can affect gut microbes and destroy intestinal homeostasis $[5,6]$. In addition, bacteria develop resistance in an increasingly fast manner, compared with the slow 
progress of new antibiotics development over the past few decades [7]. Therefore, the development of highly effective and safe antimicrobials is particularly important. Bacteriophages have once again attracted researchers' attention since they can specifically lyse bacteria and are not likely to cause bacterial resistance compared to traditional antibiotics because of their selective killing ability and co-evolution with host bacteria. It is an effective method to replace antibiotics and treat bacterial diseases. Some attempts to use bacteriophages against pathogenic bacteria in animal breeding, plant disease prevention, food manufacturing, and so on, have been reported [8-10]. So far, there have been successful cases of applying bacteriophage to the treatment of human drug-resistant bacterial infections [11-13]. With the development of research, the clinical application of bacteriophages should be more normalized and extensive.

This review mainly introduces the principle of phage therapies for bacterial infection, elaborates on the advantages of phage therapy over traditional antibiotic treatment, and summarizes the current common approaches for phage therapy. In addition, the possible obstacles, risks, and application prospects of phage therapy are discussed.

\section{Phage Therapy}

Phages are viruses that exclusively infect bacteria. They are extremely widespread in nature with the estimated number of approximate $10^{31}$, far exceeding other microorganisms [14,15]. What is more, phages play an important role in the regulation of intestinal microbiome, which is of great significance to human health [16]. Like other viruses, phages lack a complete replisome; therefore, the intracellular resources of the invaded cells are necessary for their propagation. Phages are mainly composed of capsid protein and its encapsulated nucleic acid with small volume, simple structure, and strict parasitism. Depending on their lifestyle, phages can be mainly divided into two classes: temperate phages and lytic phages (also known as virulent phages). A complete phage life cycle of the common tailed phage mainly includes the following (Figure 1): first, phages recognize specific receptors and adsorb to the surface of a host bacterium by tail fibers or spikes; then, the phages inject their own genetic material into the host bacteria; next, lytic phages make use of the host bacteria to proliferate and synthesize various components needed by themselves, complete the assembly, and form a large number of progeny phages, finally dissolving a portion of the host cell wall through the specific lysins. The progeny phages are released from the host bacteria and spread, while the host bacteria lyse and die. The lytic phage infection of bacteria is so robust that the lytic phage particle still has a strong lethality after several infection cycles. These properties of lytic phages make some of them particularly effective in treating bacterial diseases. For instance, Acinetobacter baumannii is a Gram-negative opportunistic pathogen that can be easily spread in the intensive care unit of a hospital [17]. Additionally, most of the clinically isolated A. baumannii are multidrug-resistant [18], which greatly limits the available treatment options. Some phages have shown the ability to effectively lyse drug-resistant $A$. baumannii both in vitro and in vivo [19].

Temperate phages have a choice between the lytic pathway and an alternative lysogenic pathway. In the latter pathway, phages integrate their own genetic material into the host's chromosome, replicate, and co-exist stably with the host bacteria as prophages. There is another type of temperate phage which replicates in bacteria by permanent slow release of progeny without cell lysis, which is designated as permanent infection. These prophages can be maintained in lysogens as plasmids [20,21]. Certain conditions such as induction with DNA-damaging agents (such as UV radiation and chemicals) will trigger most prophages in a population to re-activate; thus, prophages will stop its dormancy and enter the lytic cycle, further replicating phages and lysing the host [22-24]. Nonetheless, temperate phages are often not used for phage therapy because they tend not to cause host bacterial lysis until a right condition, and they will prevent subsequent phage entry once a host is infected. Additionally, they are often vectors of horizontal gene transfer, resulting in the transfer of virulent or resistant genes as well as other risks $[25,26]$. 


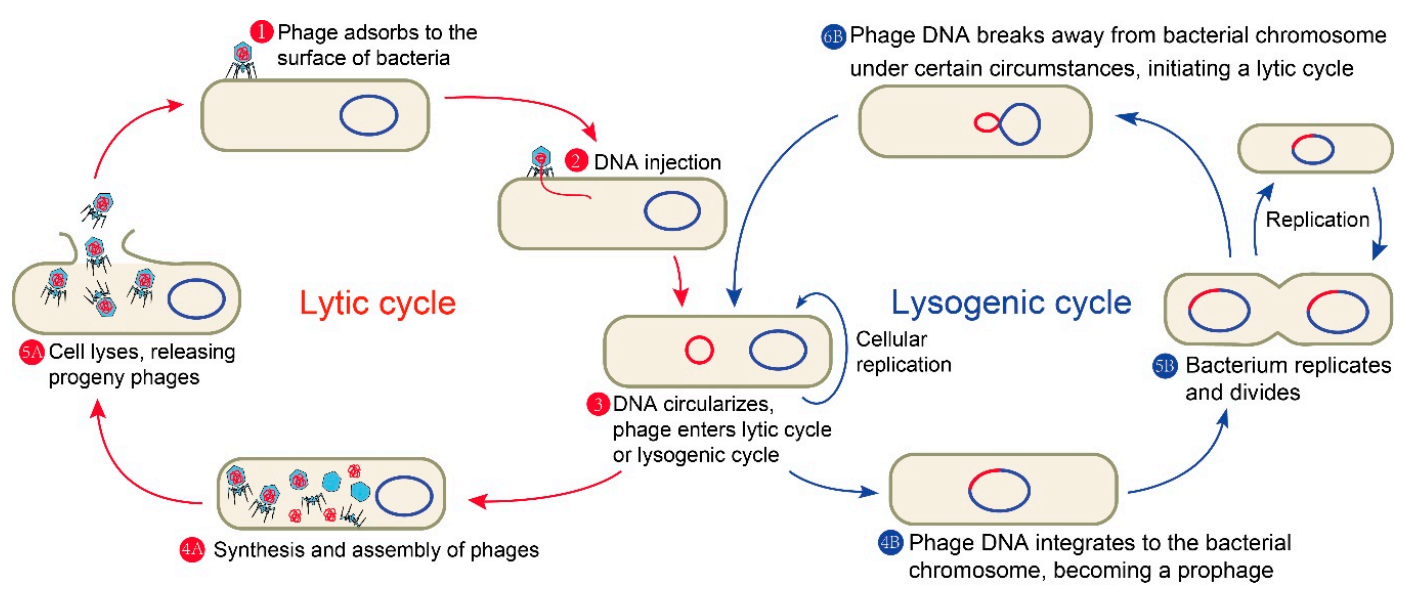

Figure 1. A complete phage life cycle of the common tailed phage.

Phage therapy has some obvious advantages over conventional antibiotics in the treatment of bacterial diseases. Firstly, as a natural antibacterial agent, phages can effectively target Gram-positive and Gram-negative bacteria. At the same time, phages only specifically target their corresponding host, and they do not affect the non-target bacteria; therefore, unlike antibiotics, phages pose no risk of destroying other normal microbiome in the body. Unlike antibiotics inhibiting a single bacterial physiological process, phages affect multiple bacterial physiological processes [12,27]. Although bacteria could develop resistance to phages, as they did to antibiotics, phages can continuously replicate and change as a living organism coexisting with host bacteria, and the mutation rate of phage is faster than that of host bacteria; thus; phages are less likely to develop bacterial resistance than antibiotics [27]. Besides, no serious side effect caused by phage therapies was reported in the previous studies [28]. Only when the phage lyses the host bacteria, the host bacteria will release endotoxin which also applies to antibiotics [29]. In addition, phage resources are abundant in nature, and the corresponding phage can be generally found in the environment containing a certain pathogen [14]. Thus, most phages can be isolated from the environment except those phages whose host bacteria are difficult to cultivate [30]. Thus, phage therapy is faster and more economical than antibiotic therapy. Phage therapy is considered a promising alternative to antibiotic therapy to control multidrug-resistant bacteria.

\section{Strategies for Phage Therapy}

As the problem of bacterial resistance becomes more and more serious, the harm caused by drug-resistant bacterial infection is considerable. Many attempts and progress have been made to use phages to treat drug-resistant bacterial infections [11,13]. Current major strategies for phage therapy include phage cocktails, the development of phage-derived enzymes, a combination of phage and antibiotics, phage engineering and the emerging combination of the phage and the clustered regularly interspaced short palindromic repeats-associated (CRISPR-Cas) system (Figure 2). 


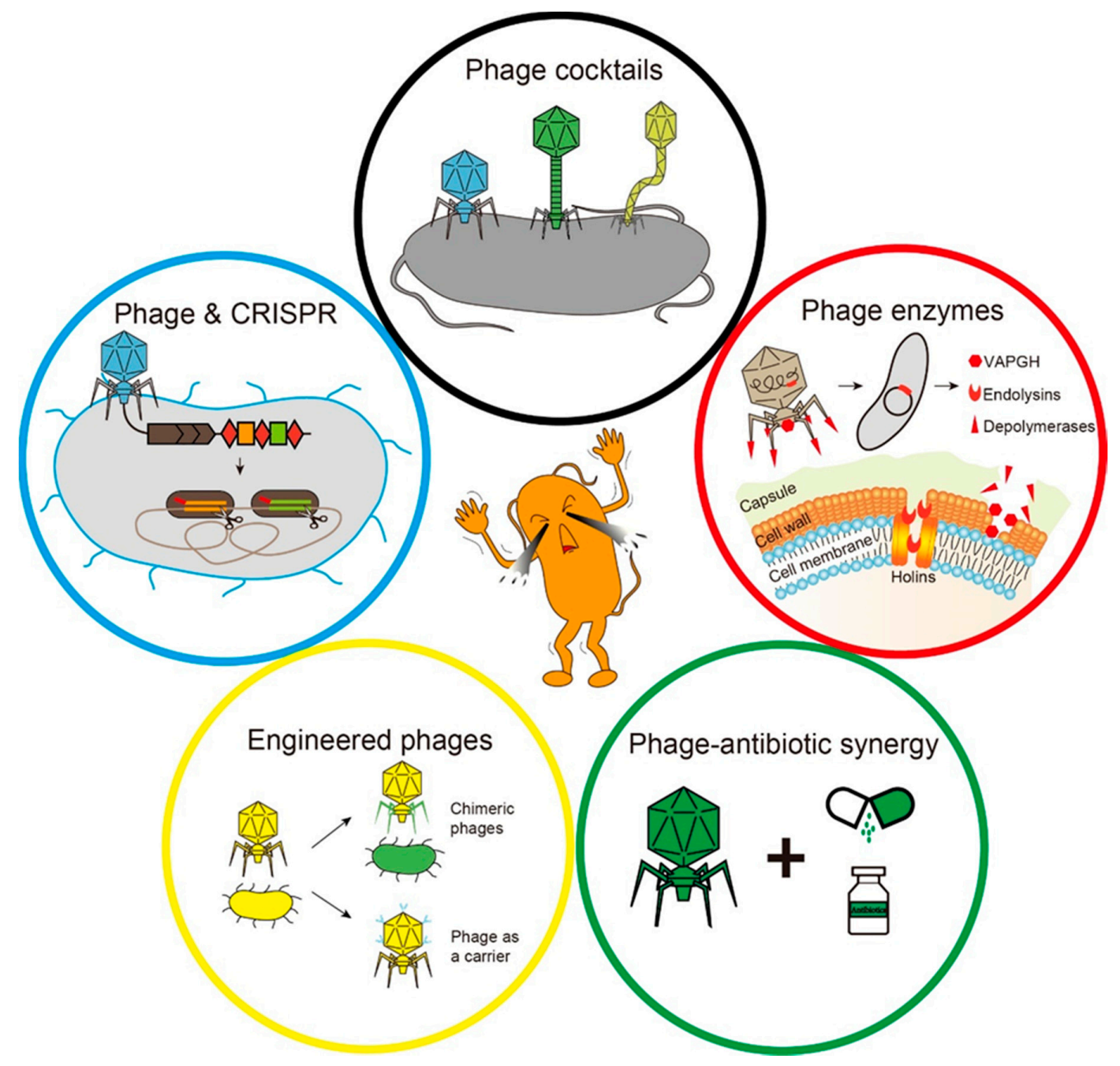

Figure 2. The main strategies for phage therapy. The black circle indicates that a variety of phages form a phage cocktail. The red circle indicates specific lysis of bacteria by phage-derived enzymes. The green circle represents the synergy between phages and antibiotics. The yellow circle represents phage engineering. The blue circle indicates that the phage delivers the clustered regularly interspaced short palindromic repeats-associated (CRISPR-Cas) system to eliminate host cells.

Some representative studies and reports on phage therapy in recent years are listed in Table 1. 
Table 1. Representative studies and reports on phage therapy in recent years.

\begin{tabular}{|c|c|c|c|c|}
\hline Pathogen & Methods & Model & Outcome & Ref. \\
\hline Escherichia coli & $\begin{array}{l}\text { Engineered phage } \\
\text { T7 to express DspB }\end{array}$ & $\begin{array}{l}\text { The efficacy of } \\
\text { biofilm removal } \\
\text { assay in vitro }\end{array}$ & $\begin{array}{l}\text { Engineered } \\
\text { enzymatic phage } \\
\text { substantially } \\
\text { reduced bacterial } \\
\text { biofilm cell counts. }\end{array}$ & [31] \\
\hline $\begin{array}{l}\text { Chlamydia } \\
\text { trachomatis }\end{array}$ & $\begin{array}{l}\text { Engineered M13 } \\
\text { phage carrying two } \\
\text { functional peptides }\end{array}$ & $\begin{array}{c}\text { Chlamydia } \\
\text { trachomatis } \\
\text { infection model in } \\
\text { both HeLa and } \\
\text { primary } \\
\text { endocervical cells }\end{array}$ & $\begin{array}{l}\text { Engineered phages } \\
\text { were able to } \\
\text { significantly reduce } \\
\text { Ct infection in both } \\
\text { HeLa and primary } \\
\text { endocervical cells } \\
\text { compared with Ct } \\
\text { infection alone. }\end{array}$ & [32] \\
\hline Escherichia coli & $\begin{array}{l}\text { Phage T4 and } \\
\text { cefotaxime }\end{array}$ & $\begin{array}{l}\text { In vitro eradication } \\
\text { of biofilms }\end{array}$ & $\begin{array}{l}\text { Combinations of } \\
\text { bacteriophage T4 } \\
\text { and cefotaxime } \\
\text { significantly } \\
\text { enhanced the } \\
\text { eradication of } \\
\text { bacterial biofilms } \\
\text { when compared to } \\
\text { treatment with } \\
\text { cefotaxime alone. }\end{array}$ & [33] \\
\hline $\begin{array}{l}\text { Beta-hemolytic } \\
\text { Streptococcus } \\
\text { agalactiae }\end{array}$ & $\begin{array}{c}\text { PlySK1249, a novel } \\
\text { phage lysin }\end{array}$ & $\begin{array}{c}\text { Streptococcus } \\
\text { agalactiae infection } \\
\text { model of mouse }\end{array}$ & $\begin{array}{l}\text { Significantly } \\
\text { protected the mice } \\
\quad(p<0.01) \\
\text { compared to the } \\
\text { control groups. }\end{array}$ & [34] \\
\hline Chlamydia abortus & $\begin{array}{c}\text { An ompA-based } \\
\text { phage-mediated } \\
\text { DNA chlamydial } \\
\text { vaccine }\end{array}$ & $\begin{array}{l}\text { Weaned piglets } \\
\text { model }\end{array}$ & $\begin{array}{l}\text { The } \lambda \text { phage-based } \\
\text { vaccine is capable } \\
\text { of inducing } \\
\text { antigen-specific } \\
\text { cellular and } \\
\text { humoral immune } \\
\text { responses. }\end{array}$ & [35] \\
\hline Vibrio & $\begin{array}{l}\text { Three-phages } \\
\text { cocktail }\end{array}$ & $\begin{array}{l}\text { Vibrio in } \\
\text { aquaculture }\end{array}$ & $\begin{array}{l}\text { The use of phage } \\
\text { cocktails of two or } \\
\text { three phages } \\
\text { increased the } \\
\text { efficiency of phage } \\
\text { therapy against } \\
\text { Vibrio. }\end{array}$ & [36] \\
\hline Staphylococci aureus & $\begin{array}{c}\text { The RNA-guided } \\
\text { nuclease Cas } 9 \\
\text { delivered by a } \\
\text { bacteriophage }\end{array}$ & $\begin{array}{l}\text { S. aureus infection } \\
\text { in a mouse skin } \\
\text { colonization model }\end{array}$ & $\begin{array}{l}\text { Reprogramming } \\
\text { the nuclease to } \\
\text { target antibiotic } \\
\text { resistance genes } \\
\text { destroys } \\
\text { staphylococcal } \\
\text { plasmids that } \\
\text { harbor antibiotic } \\
\text { resistance genes } \\
\text { and immunizes } \\
\text { avirulent } \\
\text { staphylococci to } \\
\text { prevent the spread } \\
\text { of plasmid-borne } \\
\text { resistance genes. }\end{array}$ & [37] \\
\hline
\end{tabular}


Table 1. Cont.

\begin{tabular}{|c|c|c|c|c|}
\hline Pathogen & Methods & Model & Outcome & Ref. \\
\hline Escherichia coli & $\begin{array}{l}\text { CRISPR-Cas9 } \\
\text { systems delivered } \\
\text { by phages }\end{array}$ & $\begin{array}{l}\text { Galleria mellonella } \\
\text { infection model }\end{array}$ & $\begin{array}{c}\text { Delivery of } \\
\text { RNA-guided } \\
\text { nucleases (RGNs) } \\
\text { significantly } \\
\text { improves survival } \\
\text { in a Galleria } \\
\text { mellonella } \\
\text { infection model. }\end{array}$ & [38] \\
\hline $\begin{array}{c}\text { Methicillin-resistant } \\
\text { Staphylococcus } \\
\text { aureus }\end{array}$ & $\begin{array}{l}\text { Peptidoglycan } \\
\text { hydrolases }\end{array}$ & $\begin{array}{l}\text { Systemic MRSA } \\
\text { infection in a } \\
\text { mouse model }\end{array}$ & $\begin{array}{l}\text { In a mouse model } \\
\text { of systemic MRSA } \\
\text { infection, six PGHs } \\
\text { provided } 100 \% \\
\text { protection from } \\
\text { death, with } \\
\text { animals being free } \\
\text { of clinical signs at } \\
\text { the end of the } \\
\text { experiment. }\end{array}$ & [39] \\
\hline $\begin{array}{l}\text { Multidrug-resistant } \\
\text { Acinetobacter } \\
\text { baumannii }\end{array}$ & The lysin PlyF307 & $\begin{array}{c}\text { Acinetobacter } \\
\text { baumannii infection } \\
\text { of mouse model }\end{array}$ & $\begin{array}{l}\text { Treatment with } \\
\text { PlyF307 was able to } \\
\text { significantly reduce } \\
\text { planktonic and } \\
\text { biofilm of } A \text {. } \\
\text { baumannii both } \\
\text { in vitro and } \\
\text { in vivo. }\end{array}$ & [40] \\
\hline $\begin{array}{l}\text { Pathogenic Yersinia } \\
\text { and Klebsiella }\end{array}$ & $\begin{array}{l}\text { A synthetic biology } \\
\text { strategy to } \\
\text { modulate phage } \\
\text { host ranges by } \\
\text { engineering phage } \\
\text { genomes. }\end{array}$ & $\begin{array}{l}\text { In vitro plaque } \\
\text { formation assays }\end{array}$ & $\begin{array}{c}\text { Redirect Escherichia } \\
\text { coli phage scaffolds } \\
\text { to target } \\
\text { pathogenic Yersinia } \\
\text { and Klebsiella } \\
\text { bacteria, and } \\
\text { conversely, } \\
\text { Klebsiella phage } \\
\text { scaffolds to target } \\
\text { E. coli by modular } \\
\text { swapping of phage } \\
\text { tail components. }\end{array}$ & [41] \\
\hline $\begin{array}{l}\text { Acinetobacter } \\
\text { baumannii }\end{array}$ & $\begin{array}{l}\text { Five-member } \\
\text { cocktail }\end{array}$ & $\begin{array}{l}\text { Mouse } \\
\text { full-thickness } \\
\text { dorsal infected } \\
\text { wound model }\end{array}$ & $\begin{array}{l}\text { The cocktail lowers } \\
\text { the bioburden in } \\
\text { the wound, } \\
\text { prevents the spread } \\
\text { of infection and } \\
\text { necrosis to } \\
\text { surrounding tissue, } \\
\text { and decreases } \\
\text { infection-associated } \\
\text { morbidity. } \\
\text { This phage }\end{array}$ & [42] \\
\hline $\begin{array}{l}\text { Methicillin-resistant } \\
\text { Staphylococcus } \\
\text { aureus }\end{array}$ & $\begin{array}{l}\text { Seven-phages } \\
\text { cocktail }\end{array}$ & $\begin{array}{l}\text { Chronic } \\
\text { osteomyelitis in } \\
\text { rabbit models }\end{array}$ & $\begin{array}{l}\text { This phage } \\
\text { treatment was } \\
\text { effective in } \\
\text { reducing the } \\
\text { severity of disease } \\
\text { in rabbits. }\end{array}$ & [43] \\
\hline Clostridium difficile & $\begin{array}{l}\text { 2- and 4-phage } \\
\text { combination }\end{array}$ & $\begin{array}{c}\text { C. difficile } \\
\text { colonization in a } \\
\text { hamster model }\end{array}$ & $\begin{array}{l}\text { Reduction in } C \text {. } \\
\text { difficile in treated } \\
\text { versus control } \\
\text { animals with } \\
\text { extended survival } \\
\text { in treated animals. }\end{array}$ & [44] \\
\hline
\end{tabular}


Table 1. Cont

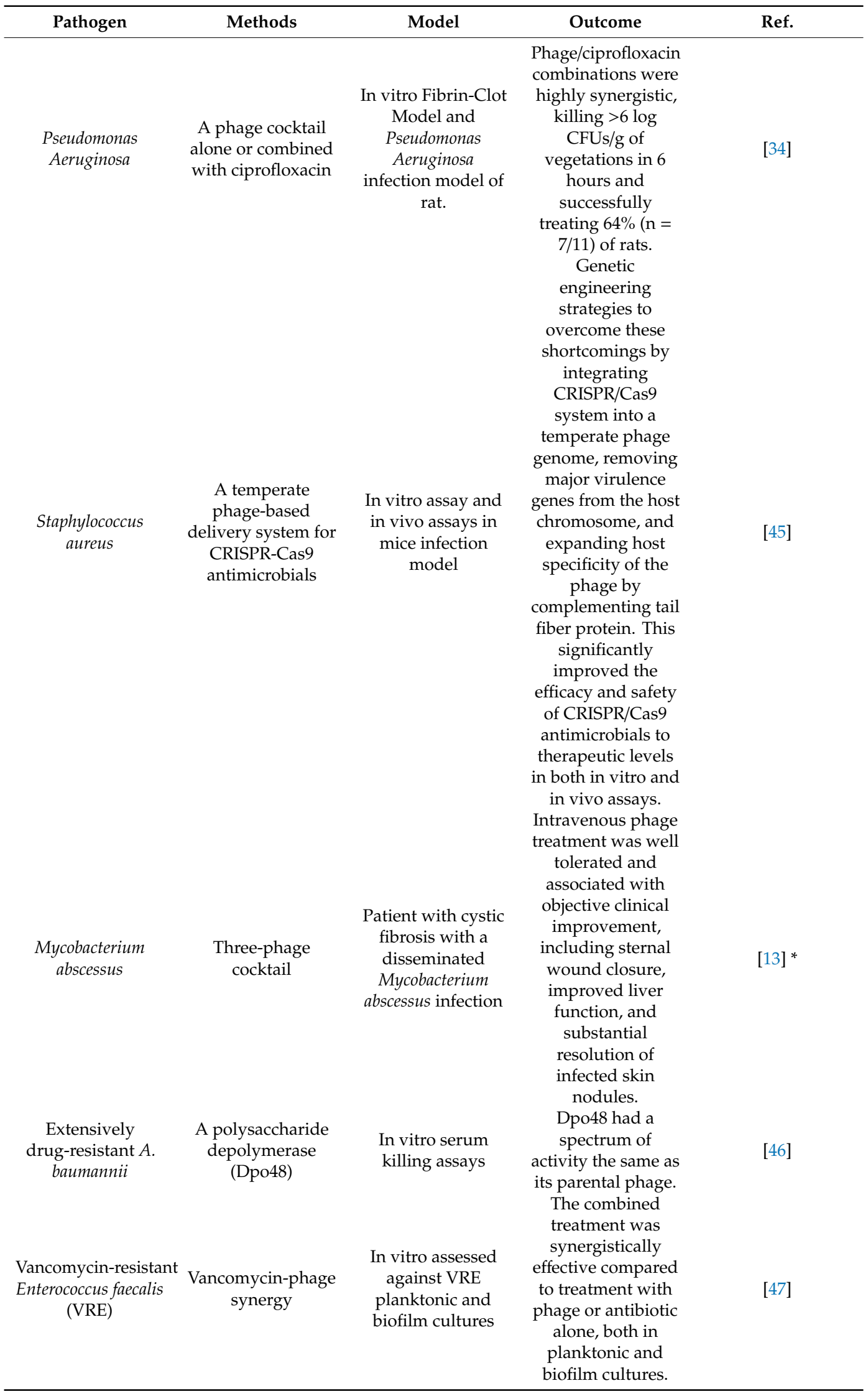


Table 1. Cont.

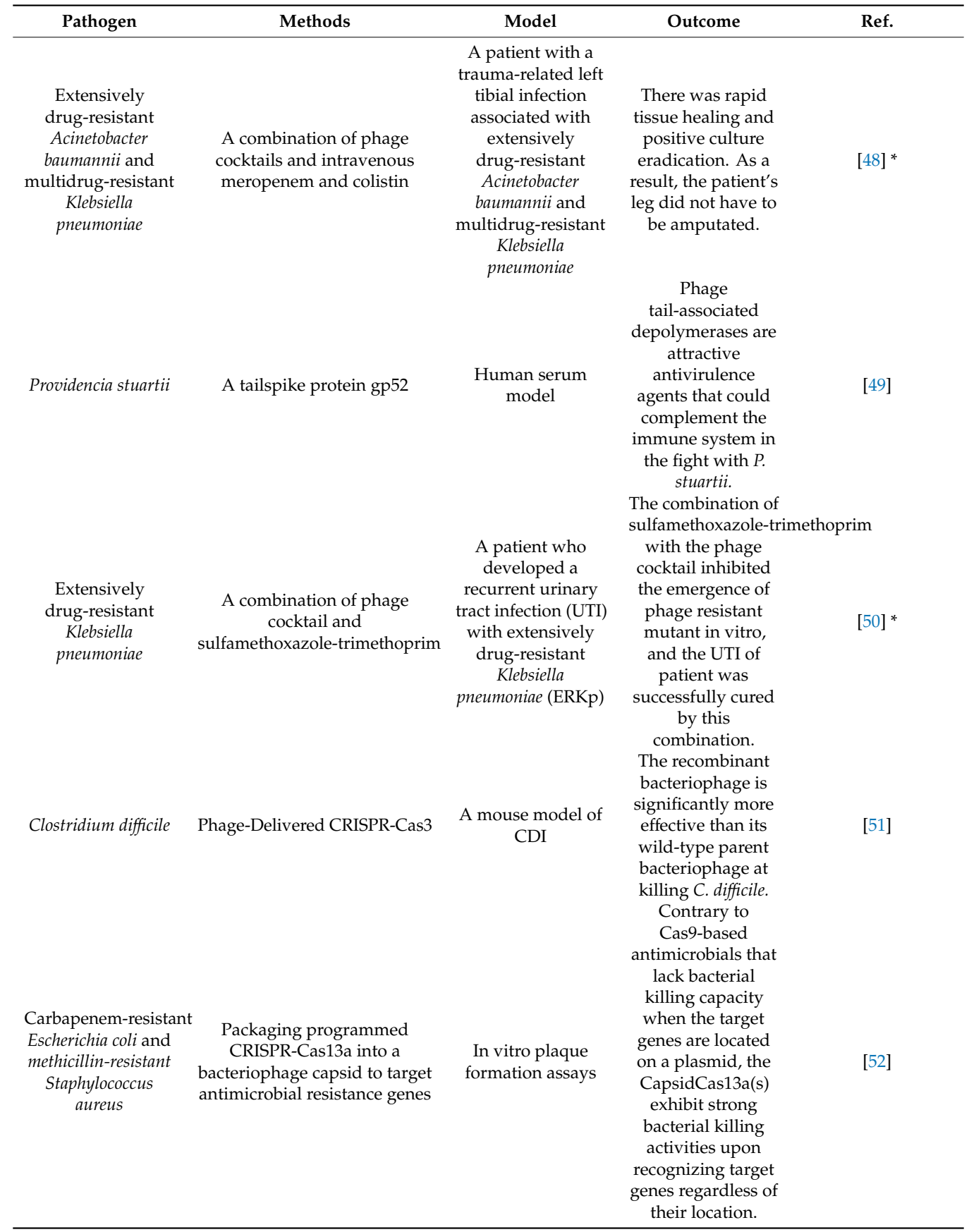

* Indicates treatment cases of human patients.

\subsection{Phage Cocktails}

Phage cocktail, as a combination of phages, is used to target a single or multiple bacterial pathogen. This method can overcome the shortcomings of the narrow phage lysis spectrum while also delaying the resistance of bacteria to phage, thus enhancing the antibacterial effect [8]. In the former Soviet Union countries, the use of bacteriophages to treat Staphylococcus aureus infections is very common [53]. Metagenomics analysis of commercial phage cocktail products used to treat skin and wound infections revealed substantial differences in phage types against Escherichia coli, Enterococcus, Salmonella, Pseudomonas aeruginosa, and Proteus, suggesting the diverse strategies for making phage cocktails against these bacterial pathogens, and no virulence factors or antibiotic resistance genes were 
detected, and no adverse reactions were reported in any treatment group, supporting the clinical safety of these commercial phage cocktail products [53]. The phage cocktail has exhibited superior ability to mono phage therapy with a much lower rate of bacteria's resistance to phages $[19,54-56]$. In a mouse full-thickness dorsal-infected wound model, a five-member cocktail can reduce the A. baumannii number in the wound to prevent the spread of infection to surrounding tissues, thus decreasing infection-associated morbidity [42]. It has been reported that the use of phage cocktails with two or three phages improved the efficiency of phage therapy against Vibrio in aquaculture [36]. Besides, in animal models, the effectiveness of phage cocktails has been confirmed against Methicillin-resistant S. aureus and Clostridium difficile, respectively $[43,44]$. A recent study showed a significant improvement in the application of three-phage cocktail to a 15-year-old cystic fibrosis patient with diffusive Mycobacterium abscessus infection after bilateral lung transplantation [13]. Taken together, all these reports indicated the feasibility and safety of phage cocktail therapy.

\subsection{Phage-Derived Enzymes}

In the life cycle of phages, a number of enzymes encoded in phage genomes could breach bacterial cells, such as virion-associated peptidoglycan hydrolases (VAPGH), endolysins, and polysaccharide depolymerases. Virion-associated peptidoglycan hydrolases (VAPGH) mostly located on the phage base plate punch holes through degrading the peptidoglycan of the bacterial cell wall to inject the phage genetic material during the adsorption of phages [57]. VAPGHs are specific and stable; therefore, they are potential candidates as new antimicrobials, but they are rarely studied and applied in clinical treatment [28]. In contrast, at the end of the lytic cycle, phages lyse host bacteria and release the viral progeny, which mainly rely on the action of their own lytic enzymes. As early as 1958, Jacob et al. discovered a class of proteins encoded by a phage that can lyse bacteria, and named it endolysin (lysin); more importantly, they found that the lysins obtained from either the U.V. induction of lysogenic Escherichia coli $\mathrm{K} 12$ or the infection of sensitive E. coli $\mathrm{K} 12$ with $\lambda$ phages also were able to lyse E. coli K12 cells [58]. Phage lysin, as a class of peptidoglycan hydrolases, can directly destroy the peptidoglycan of a bacterial cell wall [59]. Phage lysin is also considered a potential alternative to antibiotics and exhibits some obvious advantages over phages. First of all, phage lysins are highly species specific, and they do not cause damage to the body's cells, or disrupt the homeostasis of normal bacteria [39]. Second, compared with phages, lysins have a broader lysis spectrum, and they are less likely to lead to the emergence of a resistant pathogen. Rashel et al. successfully purified a lysin encoded by an S. aureus bacteriophage phi MR11; this lysin could quickly and completely lyse cells of many tested S. aureus strains, including methicillin-resistant $S$. aureus (MRSA) and vancomycin-resistant $S$. aureus (VRSA), and the lysin resistance was not observed [39,60,61]. Finally, as a kind of protein, phage lysin's physicochemical properties lysins spectrum are easier to be improved.

In addition to the VAPGH and endolysins, many bacteriophages encode depolymerases [62,63]. Phage-encoded depolymerases hydrolyze polysaccharide compounds of bacteria, such as capsule, lipopolysaccharide (LPS), or extracellular polysaccharides of biofilms [64,65]. Bacterial capsule and biofilm help bacteria to resist the action of antibiotics, disinfectants, and phagocytes. Therefore, using depolymerases to destroy these protective barriers of pathogens can efficiently improve the therapeutic effect of bacterial infection. For example, a polysaccharide depolymerase (Dpo48) from the A. baumannii phage IME200 was found to degrade the capsule of bacteria and to have the same activity spectrum with its parental phage [46]. Oliveira et al. found that a phage tail-associated depolymerase (protein gp52) could enhance the immune system against Providencia stuartii in a human serum model [49]. Some studies have also confirmed that certain new lysins can effectively protect animals from pathogens such as beta-hemolytic Streptococcus agalactiae and multidrug-resistant A. baumannii [34,40]. All these findings suggest that phage-derived enzymes are potential antimicrobials and promising alternatives to antibiotics. Moreover, the convenient industrial production of enzymes will promote their applications. 


\subsection{Phage and Phage Enzymes Combined with Antibiotics}

Phages are considered to be a promising alternative to antibiotics, but multiple studies have shown that co-treatments with phages and antibiotics could achieve a better therapeutic effect than individual treatment. Phage-antibiotic synergy (PAS) was first proposed in 2007, referring to the phenomenon that the sub-lethal concentrations of certain antibiotics can significantly stimulate the propagation of lytic bacteriophages in the host bacteria, thus leading to accelerated cleavage of host cells and rapid diffusion of progeny phages [66]. Biofilm formation helps bacteria to prevent antibiotic action, but the bacterium number was more significantly decreased when lytic phage-producing depolymerase and ciprofloxacin unite to treat the biofilm of Klebsiella pneumoniae than when ciprofloxacin was used alone [67]. The synergy between phage and conventional antibiotics can substantially improve the eradication of bacterial biofilms [33]. As mentioned in the previous section of this paper, phages produce depolymerases to specifically degrade exopolysaccharides in biofilm, so that antibiotics can attack the bacteria protected by biofilms. Shlezinger et al. found that the combined treatment of Vancomycin-phage EFLK1 (anti-Enterococcus faecalis phage) was more effective than treatment with phage or antibiotic alone both in planktonic and biofilm cultures of vancomycin-resistant $E$. faecalis (VRE) [47]. In addition, phage was used in combination with nisin to reduce planktonic and biofilm cells of S. aureus [68]. The combination of phages and antibiotics can not only enhance the antibacterial effect, but also reduce the emergence of bacterial resistance [69]. In a P. Aeruginosa infection rat model, phage-ciprofloxacin combinations were highly synergistic [34]. Recently, the combination of sulfamethoxazole-trimethoprim and the phage cocktail effectively inhibit the occurrence of bacterium resistance to phage and cure the urinary tract infection with extensively drug-resistant K. pneumonia [50]. Nir-Paz et al. successfully cured a patient infected with extensively drug-resistant $A$. baumannii and multidrug-resistant K. pneumoniae by a combination of phage cocktail and intravenous meropenem and colistin [48]. Likewise, the aforementioned phage-derived enzymes can also be used in combination with other drugs. In animal experiments, the combination therapy of a lysine LysGH15 and apigenin also shows a better treatment effect than LysGH15 or apigenin monotherapy [70]. At the same time, it should be noted that some antibiotics may have potential antagonistic effects on phage infection, and that the concentration of antibiotics and the order of addition will also have a great impact on the synergistic effect [71-73].

\subsection{Phage Engineering}

Genetic engineering technology has greatly promoted life science research and application, including phage therapy. In addition to the phage cocktail, another solution to overcome the narrow lysis spectrum of a phage and inhibit the bacterial resistance is phage genetic engineering. Phage engineering can increase phage therapeutic potential, by expanding or changing lysis spectrum or/and delivering exogenous genes and proteins. One of the most common methods is to engineer genes encoding receptor-binding proteins (RBPs) in the tail fibers or spikes of phages to obtain a broad spectrum [74]. In a previous study, the chimeric phage is obtained by homologous recombination of the anti-receptor gene orf18 of Streptococcus thermophilus phage DT1 and siphovirus MD4, and this chimeric phage acquired the host range of phage MD4 [75]. Mahichi et al. constructed a chimeric $E$. coli phage T2 with broader lysis spectrum by embedding the long tail fiber genes of phage IP008 into phage T2 through homologous recombination [76]. In 2015, Ando et al. established a yeast-based high-throughput platform to change the phage host range through the modular swapping of phage tail components, and the obtained synthetic phages were able to effectively kill their new target bacteria for bacterial population editing [41]. In combination with bioinformatics analysis and the RBP crystal structure analysis, Dunne et al. constructed a synthetic phage library containing random sequence RBP and screened a polyvalent phage with an extended host range [77]. Meanwhile, Yehl et al. identified host-range-determining regions (HRDRs) of the T3 phage and synthesized the phages through the site-directed mutagenesis of these regions to alter host range and suppress bacterial resistance [78]. All these make it possible for us to exploit ordinary phages to construct novel phages that can kill 
specific pathogens. Lu and Collins engineered E. coli phage T7, as a phage carries to express the enzyme dispersin $\mathrm{B}$ capable of degrading the extracellular polymers of bacterial biofilm, and this engineered enzymatic phage reduces the bacterial biofilm cell number by 2 orders of magnitude, compared with the wild-type phage [31]. The $\lambda$ phage-based vaccine is capable of inducing antigen-specific cellular and humoral immune responses [35]. Engineered M13 phages with two functional peptides are able to significantly reduce Chlamydia trachomatis infection in both HeLa and primary endocervical cells [32]. A successful case of using a modified phage cocktail for curing a 15-year-old patient with cystic fibrosis with a diffused M. abscessus infection was reported [13]. Furthermore, phages have been used to deliver toxins [79], chloramphenicol [80], photosensitizing agents [81] and functional genes (such as CRISPR-Cas, see the next section for details) for therapeutic purposes.

\subsection{Phage Combined with CRISPR-Cas System}

Strictly speaking, the combination of a phage and CRISPR-Cas system is also a kind of phage engineering, but we list it separately as a section here, mainly because of its novelty and importance. The clustered regularly interspaced short palindromic repeats-associated (CRISPR-Cas) system in bacteria and archaea provides sequence-based adaptive immunity against mobile genetic elements such as viruses and plasmids [82]. In general, the CRISPR-Cas system acts by integrating the short fragments of nucleic acid of viruses or plasmids into the CRISPR array and produce short RNA sequences complementary to them (known as CRISPR RNAs, namely crRNAs), and these resultant crRNAs guide Cas protein complex to specifically target invading foreign genetic elements for degradation [83]. Based on the precise sites interference of CRISPR-Cas and the high infection efficiency of a phage, we can implement the delivery of the CRISPR-Cas system with phage to specifically target bacterial genomic DNA (or RNA) so as to eliminate pathogenic bacteria and prevent the emergence of bacterial resistance [84]. For the target bacteria containing an active endogenous CRISPR-Cas system, we only need to embed a mini-CRISPR array into the phage genome so as to express the artificial crRNA matching drug-resistant bacterial genome. In short, the endogenous CRISPR-Cas system is exploited by bacteriophage to attack its host cell [85]. More recently, after a phage encodes bacterial genome-targeting CRISPR array, the endogenous CRISPR-Cas3 in C. difficile is repurposed as an antimicrobial, resulting in the bacterial cells death through the phage infection lysis or CRISPR effector complexes self-targeting [51]. For the pathogens without a CRISPR-Cas system, an additional, exogenous CRISPR nuclease could be a good choice. In several previous studies, it has been reported that the use of phagemids with exogenous CRISPR-Cas9 system results in the specific and rapid bacteria targeting [38], and that the programmed CRISPR-Cas13a is packed into a bacteriophage capsid to target antimicrobial resistance genes [52]. Similarly, S. aureus phage $\varphi$ NM1 is used to deliver an exogeneous CRISPR-Cas system to eliminate the pathogenic host [37]. A temperate phage-based delivery system is used to deliver CRISPR/Cas9 against bacteria [45]. Excitingly, some phages encode their own CRISPR-Cas systems, including types II and V, which are widely used for gene editing, and the related effector proteins have complete catalytic residues, indicating that these effector proteins are functionally active [86-89]. At the same time, we should also note that some bacterial genomes encode anti-CRISPR (Acr) proteins which can inhibit the CRISPR-Cas system in many ways [90]. Another obvious advantage of the bacteriophage combined with the CRISPR-Cas system is that it allows bacteriophages to be programmed to kill only antibiotic-resistant bacteria while protecting antibiotic-sensitized bacteria, which is of great significance to avoiding the emergence of resistant bacteria [91]. To sum up, the phage combined with CRISPR-Cas system has a splendid application prospect in the prevention and treatment of drug-resistant bacteria.

\section{Barriers and Limitations of Phage Therapy}

Although phage therapy has obvious advantages over antibiotic therapy, phage therapy as well as the related problems remain to be further investigated. There are still some obstacles to be overcome before the large-scale introduction of phage therapy to the clinic. 
Firstly, the strict specificity of phages to the host bacteria is a very good advantage over antibiotics. At the same time, the narrow lysis spectrum limits the effectiveness of bacteriophages in killing a variety of bacteria. This limitation can be partly overcome by phage cocktail therapy, utilizing phage lyases, and engineering a phage for the broader host spectrum. In the process of phage therapy, it is necessary to identify the pathogen to select the effective phage, and a bacterial disease is usually caused by a variety of pathogens. In addition, the development of phage resources still needs a lot of work, and some studies have shown that some bacteriophages are difficult to isolate [12,30].

Secondly, bacteria have evolved a series of defense mechanisms to press the stop button in different stages of the phage infection cycle, including an intracellular restriction modification system, abortive infection, phage exclusion, superinfection exclusion, a CRISPR-Cas system, Acr protein, etc. $[90,92]$. In addition, bacteria also become resistant to phages by modifying the receptor on the cell surface, blocking effect of outer membrane vesicles, and quorum sensing effect during the co-evolution between phage and bacteria [27,92-94]. Moreover, as a bacterial virus, bacteriophage cannot directly penetrate eukaryotic cells unless they use bacteria as carriers, which limits the treatment of intracellular infection [12,92]. Drug therapy delivery usually uses different porous nanoparticles to carry therapeutic cargoes. However, the phage particles are nonsymmetrical and larger than the pore sizes of nanoparticles used to load them [84]. Bacterial infections can occur in any place in the body; therefore, the reasonable way of encapsulation and delivery helping phage or its derivatives to reach the site of infection is needed. Different strategies of encapsulating and stabilizing bacteriophages have been introduced to overcome the limitation of phage delivery. For example, the encapsulation of a phage in liposomes has been found to promote phage delivery to intracellular infection sites and to increase the retention time of phage in the host $[95,96]$.

As is well known, safety and effectiveness are the two most important standards of medical treatment. Due to the lack of understanding of the functional genomics of phages, phage-carried genes with unknown functions may be resistance genes and virulence factors $[26,97]$. Bacteria lysed by a phage may release endotoxins and super antigens that cause inflammation, which may potentially cause serious complications $[98,99]$. For example, the phages of $S$. aureus and P. aeruginosa are able to induce endotoxin-independent anti-inflammatory response [100]. In addition, most data of the activity and growth of phages come from in vitro experiments, which may be greatly different from complex in vivo environments. On the other hand, the pharmacokinetics of the phage during the treatment process are not well-known, especially those in the multiple species used for phage cocktails.

Phages mainly eliminate bacteria through active treatment and passive treatment. Phages at high concentrations can directly kill bacteria (known as passive treatment), which is consistent with traditional antibiotic treatment. However, the treatment outcome is highly dependent on the quantity ratio between phage and host bacteria in active treatment. When it infects its host bacteria, a phage will be resisted by the defense systems of the host bacteria. Only when the host bacteria reach a certain biomass can the phage replicate and proliferate [93,101]. All these suggest that it is very important to optimize the initial time of phage therapy and the dose of phage. With the increasing demand for phage to treat drug-resistant bacterial infections, the safety standards and relevant legislations for production and clinical implementation are urgently needed [12,102].

\section{Conclusions and Outlook}

The discovery and application of antibiotics have made a great contribution to fight against pathogens and saving lives in the history of human beings. However, the development of traditional antibiotics is becoming more and more difficult, and the problem of bacterial resistance is becoming increasingly prominent, which has posed a serious threat to human health. In addition to the standardized management and use of antibiotics, the development of new antimicrobial agents that can replace antibiotics is also particularly important. Bacteriophages can specifically lyse bacteria and are relatively safe for eukaryotic cells. Therefore, phage therapy is a very attractive solution to fight against drug-resistant bacteria. 
In recent years, more and more in vitro and in vivo studies have shown the ability of bacteriophages to prevent and treat drug-resistant bacteria. There have been some successful cases of curing patients infected by drug-resistant bacteria (Table 1). In addition to the pioneering studies in Poland and the former Soviet Union, there are great advancements in phage therapy. However, there are still many challenges to be solved before using phages for clinical treatment, including the identification of phage-resistant bacteria, further study of the pharmacokinetics of phage, the interaction between phage and human tissues, and any potential human immunity response caused by phage therapy. At the same time, how to choose the most suitable bacteriophage or its derivatives, how to determine the dosage, and how to use it are all worthy of consideration. In addition, phage therapy as well as its combination with conventional antibiotics should be given priority in the treatment of patients with bacterial infections. This will greatly reduce the use of antibiotics, and it is also of great significance to control the emergence of antibiotic-resistant bacteria.

Although we are still a long way from the large-scale application of phage therapy, it is time to embrace phage therapy with determination and enthusiasm. We are pleased to see some new attempts at phage therapy which have shown great prospect, such as the combination of a phage and CRISPR-Cas system and the phage engineering. The recent successful case of treatment of patients with engineered phage has greatly encouraged us [13]. Engineering a phage by, for example, combining with CRISPR-Cas or endowing the phage with a stronger lysis ability, replication ability, and stronger stress resistance through genetic engineering, will be the future development trend. In addition, with the development of genomics and bioinformatics, computer algorithms may be used to select suitable bacteriophages, and reliable models are used to generate enough useful data to predict the effects of phage therapy against pathogens that are difficult to cultivate in the laboratory.

Author Contributions: J.W., N.P., Y.L. (Yunxiang Liang), K.L. and Y.L. (Yingjun Li) conceived the ideas presented in this manuscript. J.W. and Y.L. (Yingjun Li) collected the literature, wrote and approved the manuscript. All authors have read and agreed to the published version of the manuscript.

Funding: This research was funded by the National Natural Science foundation of China (31801035), National Postdoctoral Program for Innovative Talents (BX201800113), Hubei Provincial Natural Science Foundation of China (2018CFB223).

Acknowledgments: Great gratitude goes to linguistics Ping Liu from Foreign Language College, Huazhong Agriculture University, Wuhan, China for her work at English editing and language polishing.

Conflicts of Interest: The authors declare no conflict of interest.

\section{References}

1. Dublanchet, A.; Fruciano, E. A short history of phage therapy. Med. Mal. Infect. 2008, 38, 415-420. [CrossRef] [PubMed]

2. Salmond, G.P.C.; Fineran, P.C. A century of the phage: Past, present and future. Nat. Rev. Microbiol. 2015, 13, 777-786. [CrossRef] [PubMed]

3. Żaczek, M.; Weber-Dabrowska, B.; Międzybrodzki, R.; Łusiak-Szelachowska, M.; Górski, A. Phage Therapy in Poland-a Centennial Journey to the First Ethically Approved Treatment Facility in Europe. Front. Microbiol. 2020, 11, 1056. [CrossRef] [PubMed]

4. Dodds, D.R. Antibiotic resistance: A current epilogue. Biochem. Pharmacol. 2017, 134, 139-146. [CrossRef]

5. Becattini, S.; Taur, Y.; Pamer, E.G. Antibiotic-Induced Changes in the Intestinal Microbiota and Disease. Trends Mol. Med. 2016, 22, 458-478. [CrossRef]

6. Ianiro, G.; Tilg, H.; Gasbarrini, A. Antibiotics as deep modulators of gut microbiota: Between good and evil. Gut 2016, 65, 1906-1915. [CrossRef]

7. Lewis, K. The Science of Antibiotic Discovery. Cell 2020, 181, 29-45. [CrossRef]

8. Liu, N.; Lewis, C.; Zheng, W.; Fu, Z.Q. Phage Cocktail Therapy: Multiple Ways to Suppress Pathogenicity. Trends Plant Sci. 2020, 25, 315-317. [CrossRef]

9. Lim, T.H.; Kim, M.S.; Lee, D.H.; Lee, Y.N.; Park, J.K.; Youn, H.N.; Lee, H.J.; Yang, S.Y.; Cho, Y.W.; Lee, J.B.; et al. Use of bacteriophage for biological control of Salmonella Enteritidis infection in chicken. Res. Vet. Sci. 2012, 93, 1173-1178. [CrossRef] 
10. Wang, X.; Wei, Z.; Yang, K.; Wang, J.; Jousset, A.; Xu, Y.; Shen, Q.; Friman, V.-P. Phage combination therapies for bacterial wilt disease in tomato. Nat. Biotechnol. 2019, 37, 1513-1520. [CrossRef]

11. Chan, B.K.; Turner, P.E.; Kim, S.; Mojibian, H.R.; Elefteriades, J.A.; Narayan, D. Phage treatment of an aortic graft infected with Pseudomonas aeruginosa. Evol. Med. Public Health 2018, 2018, 60-66. [CrossRef]

12. Kortright, K.E.; Chan, B.K.; Koff, J.L.; Turner, P.E. Phage Therapy: A Renewed Approach to Combat Antibiotic-Resistant Bacteria. Cell Host Microbe 2019, 25, 219-232. [CrossRef] [PubMed]

13. Dedrick, R.M.; Guerrero-Bustamante, C.A.; Garlena, R.A.; Russell, D.A.; Ford, K.; Harris, K.; Gilmour, K.C.; Soothill, J.; Jacobs-Sera, D.; Schooley, R.T.; et al. Engineered bacteriophages for treatment of a patient with a disseminated drug-resistant Mycobacterium abscessus. Nat. Med. 2019, 25, 730-733. [CrossRef] [PubMed]

14. Clokie, M.R.; Millard, A.D.; Letarov, A.V.; Heaphy, S. Phages in nature. Bacteriophage 2011, 1, 31-45. [CrossRef] [PubMed]

15. Mushegian, A.R. Are There 10 Virus Particles on Earth, or More, or Fewer? J. Bacteriol. 2020, 202, e00052-20. [CrossRef]

16. Hsu, B.B.; Gibson, T.E.; Yeliseyev, V.; Liu, Q.; Lyon, L.; Bry, L.; Silver, P.A.; Gerber, G.K. Dynamic Modulation of the Gut Microbiota and Metabolome by Bacteriophages in a Mouse Model. Cell Host Microbe 2019, 25, 803-814.e5. [CrossRef]

17. Murray, C.K.; Yun, H.C.; Griffith, M.E.; Thompson, B.; Crouch, H.K.; Monson, L.S.; Aldous, W.K.; Mende, K.; Hospenthal, D.R. Recovery of multidrug-resistant bacteria from combat personnel evacuated from Iraq and Afghanistan at a single military treatment facility. Mil. Med. 2009, 174, 598-604. [CrossRef]

18. Calhoun, D.A.; Jones, D.; Textor, S.; Goff, D.C.; Murphy, T.P.; Toto, R.D.; White, A.; Cushman, W.C.; White, W.; Sica, D.; et al. Resistant hypertension: Diagnosis, evaluation, and treatment: A scientific statement from the American Heart Association Professional Education Committee of the Council for High Blood Pressure Research. Circulation 2008, 117, e510-e526. [CrossRef]

19. Jasim, H.N.; Hafidh, R.R.; Abdulamir, A.S. Formation of therapeutic phage cocktail and endolysin to highly multi-drug resistant: And study. Iran. J. Basic Med. Sci. 2018, 21, 1100-1108. [CrossRef]

20. Russel, M. Filamentous phage assembly. Mol. Microbiol. 1991, 5, 1607-1613. [CrossRef]

21. Gilcrease, E.B.; Casjens, S.R. The genome sequence of Escherichia coli tailed phage D6 and the diversity of Enterobacteriales circular plasmid prophages. Virology 2018, 515, 203-214. [CrossRef] [PubMed]

22. Herskowitz, I.; Hagen, D. The lysis-lysogeny decision of phage lambda: Explicit programming and responsiveness. Annu. Rev. Genet. 1980, 14, 399-445. [CrossRef] [PubMed]

23. Brussow, H.; Canchaya, C.; Hardt, W.D. Phages and the evolution of bacterial pathogens: From genomic rearrangements to lysogenic conversion. Microbiol. Mol. Biol. Rev. 2004, 68, 560-602, table of contents. [CrossRef] [PubMed]

24. Howard-Varona, C.; Hargreaves, K.R.; Abedon, S.T.; Sullivan, M.B. Lysogeny in nature: Mechanisms, impact and ecology of temperate phages. ISME J. 2017, 11, 1511-1520. [CrossRef]

25. Dedrick, R.M.; Jacobs-Sera, D.; Bustamante, C.A.; Garlena, R.A.; Mavrich, T.N.; Pope, W.H.; Reyes, J.C.; Russell, D.A.; Adair, T.; Alvey, R.; et al. Prophage-mediated defence against viral attack and viral counter-defence. Nat. Microbiol. 2017, 2, 16251. [CrossRef]

26. Balcazar, J.L. Bacteriophages as vehicles for antibiotic resistance genes in the environment. PLoS Pathog. 2014, 10, e1004219. [CrossRef]

27. Hampton, H.G.; Watson, B.N.J.; Fineran, P.C. The arms race between bacteria and their phage foes. Nature 2020, 577, 327-336. [CrossRef]

28. Gordillo Altamirano, F.L.; Barr, J.J. Phage Therapy in the Postantibiotic Era. Clin. Microbiol. Rev. 2019, 32, e00066-18. [CrossRef]

29. Dufour, N.; Delattre, R.; Ricard, J.-D.; Debarbieux, L. The Lysis of Pathogenic Escherichia coli by Bacteriophages Releases Less Endotoxin Than by $\beta$-Lactams. Clin. Infect. Dis. Off. Publ. Infect. Dis. Soc. Am. 2017, 64, 1582-1588. [CrossRef]

30. Hyman, P. Phages for Phage Therapy: Isolation, Characterization, and Host Range Breadth. Pharmaceuticals (Basel, Switzerland) 2019, 12, 35. [CrossRef]

31. Lu, T.K.; Collins, J.J. Dispersing biofilms with engineered enzymatic bacteriophage. Proc. Natl. Acad. Sci. USA 2007, 104, 11197-11202. [CrossRef] [PubMed]

32. Bhattarai, S.R.; Yoo, S.Y.; Lee, S.W.; Dean, D. Engineered phage-based therapeutic materials inhibit Chlamydia trachomatis intracellular infection. Biomaterials 2012, 33, 5166-5174. [CrossRef] [PubMed] 
33. Ryan, E.M.; Alkawareek, M.Y.; Donnelly, R.F.; Gilmore, B.F. Synergistic phage-antibiotic combinations for the control of Escherichia coli biofilms in vitro. FEMS Immunol. Med. Microbiol. 2012, 65, 395-398. [CrossRef] [PubMed]

34. Oechslin, F.; Piccardi, P.; Mancini, S.; Gabard, J.; Moreillon, P.; Entenza, J.M.; Resch, G.; Que, Y.-A. Synergistic Interaction Between Phage Therapy and Antibiotics Clears Pseudomonas Aeruginosa Infection in Endocarditis and Reduces Virulence. J. Infect. Dis. 2016, 215, 703-712. [CrossRef] [PubMed]

35. Ou, C.; Tian, D.; Ling, Y.; Pan, Q.; He, Q.; Eko, F.O.; He, C. Evaluation of an ompA-based phage-mediated DNA vaccine against Chlamydia abortus in piglets. Int. Immunopharmacol. 2013, 16, 505-510. [CrossRef] [PubMed]

36. Mateus, L.; Costa, L.; Silva, Y.J.; Pereira, C.; Cunha, A.; Almeida, A. Efficiency of phage cocktails in the inactivation of Vibrio in aquaculture. Aquaculture 2014, 424-425, 167-173. [CrossRef]

37. Bikard, D.; Euler, C.W.; Jiang, W.; Nussenzweig, P.M.; Goldberg, G.W.; Duportet, X.; Fischetti, V.A.; Marraffini, L.A. Exploiting CRISPR-Cas nucleases to produce sequence-specific antimicrobials. Nat. Biotechnol. 2014, 32, 1146-1150. [CrossRef]

38. Citorik, R.J.; Mimee, M.; Lu, T.K. Sequence-specific antimicrobials using efficiently delivered RNA-guided nucleases. Nat. Biotechnol. 2014, 32, 1141-1145. [CrossRef]

39. Schmelcher, M.; Shen, Y.; Nelson, D.C.; Eugster, M.R.; Eichenseher, F.; Hanke, D.C.; Loessner, M.J.; Dong, S.; Pritchard, D.G.; Lee, J.C.; et al. Evolutionarily distinct bacteriophage endolysins featuring conserved peptidoglycan cleavage sites protect mice from MRSA infection. J. Antimicrob. Chemother. 2015, 70, 1453-1465. [CrossRef]

40. Lood, R.; Winer, B.Y.; Pelzek, A.J.; Diez-Martinez, R.; Thandar, M.; Euler, C.W.; Schuch, R.; Fischetti, V.A. Novel phage lysin capable of killing the multidrug-resistant gram-negative bacterium Acinetobacter baumannii in a mouse bacteremia model. Antimicrob. Agents Chemother. 2015, 59, 1983-1991. [CrossRef]

41. Ando, H.; Lemire, S.; Pires, D.P.; Lu, T.K. Engineering Modular Viral Scaffolds for Targeted Bacterial Population Editing. Cell Syst. 2015, 1, 187-196. [CrossRef] [PubMed]

42. Regeimbal, J.M.; Jacobs, A.C.; Corey, B.W.; Henry, M.S.; Thompson, M.G.; Pavlicek, R.L.; Quinones, J.; Hannah, R.M.; Ghebremedhin, M.; Crane, N.J.; et al. Personalized Therapeutic Cocktail of Wild Environmental Phages Rescues Mice from Acinetobacter baumannii Wound Infections. Antimicrob. Agents Chemother. 2016, 60, 5806. [CrossRef] [PubMed]

43. Kishor, C.; Mishra, R.R.; Saraf, S.K.; Kumar, M.; Srivastav, A.K.; Nath, G. Phage therapy of staphylococcal chronic osteomyelitis in experimental animal model. Indian J. Med. Res. 2016, 143, 87-94. [CrossRef]

44. Nale, J.Y.; Spencer, J.; Hargreaves, K.R.; Buckley, A.M.; Trzepiński, P.; Douce, G.R.; Clokie, M.R. Bacteriophage Combinations Significantly Reduce Clostridium difficile Growth In Vitro and Proliferation In Vivo. Antimicrob. Agents Chemother. 2016, 60, 968-981. [CrossRef]

45. Park, J.Y.; Moon, B.Y.; Park, J.W.; Thornton, J.A.; Park, Y.H.; Seo, K.S. Genetic engineering of a temperate phage-based delivery system for CRISPR/Cas9 antimicrobials against Staphylococcus aureus. Sci. Rep. 2017, 7, 44929. [CrossRef]

46. Liu, Y.; Mi, Z.; Mi, L.; Huang, Y.; Li, P.; Liu, H.; Yuan, X.; Niu, W.; Jiang, N.; Bai, C.; et al. Identification and characterization of capsule depolymerase Dpo48 from Acinetobacter baumannii phage IME200. PeerJ 2019, 7, e6173. [CrossRef]

47. Shlezinger, M.; Coppenhagen-Glazer, S.; Gelman, D.; Beyth, N.; Hazan, R. Eradication of Vancomycin-Resistant Enterococci by Combining Phage and Vancomycin. Viruses 2019, 11, 954. [CrossRef]

48. Nir-Paz, R.; Gelman, D.; Khouri, A.; Sisson, B.M.; Fackler, J.; Alkalay-Oren, S.; Khalifa, L.; Rimon, A.; Yerushalmy, O.; Bader, R.; et al. Successful Treatment of Antibiotic-resistant, Poly-microbial Bone Infection With Bacteriophages and Antibiotics Combination. Clin. Infect. Dis. 2019, 69, 2015-2018. [CrossRef] 
49. Oliveira, H.; Pinto, G.; Mendes, B.; Dias, O.; Hendrix, H.; Akturk, E.; Noben, J.-P.; Gawor, J.; Łobocka, M.; Lavigne, R.; et al. A Tailspike with Exopolysaccharide Depolymerase Activity from a New Providencia stuartii Phage Makes Multidrug-Resistant Bacteria Susceptible to Serum-Mediated Killing. Appl. Environ. Microbiol. 2020, 86, e00073-20. [CrossRef]

50. Bao, J.; Wu, N.; Zeng, Y.; Chen, L.; Li, L.; Yang, L.; Zhang, Y.; Guo, M.; Li, L.; Li, J.; et al. Non-active antibiotic and bacteriophage synergism to successfully treat recurrent urinary tract infection caused by extensively drug-resistant Klebsiella pneumoniae. Emerg. Microbes Infect. 2020, 9, 771-774. [CrossRef]

51. Selle, K.; Fletcher, J.R.; Tuson, H.; Schmitt, D.S.; McMillan, L.; Vridhambal, G.S.; Rivera, A.J.; Montgomery, S.A.; Fortier, L.C.; Barrangou, R.; et al. In Vivo Targeting of Clostridioides difficile Using Phage-Delivered CRISPR-Cas3 Antimicrobials. Mbio 2020, 11. [CrossRef]

52. Kiga, K.; Tan, X.E.; Ibarra-Chávez, R.; Watanabe, S.; Aiba, Y.; Sato'o, Y.; Li, F.Y.; Sasahara, T.; Cui, B.; Kawauchi, M.; et al. Development of CRISPR-Cas13a-based antimicrobials capable of sequence-specific killing of target bacteria. Nat. Commun. 2020, 11, 2934. [CrossRef]

53. McCallin, S.; Sarker, S.A.; Sultana, S.; Oechslin, F.; Brussow, H. Metagenome analysis of Russian and Georgian Pyophage cocktails and a placebo-controlled safety trial of single phage versus phage cocktail in healthy Staphylococcus aureus carriers. Environ. Microbiol. 2018, 20, 3278-3293. [CrossRef]

54. Yang, Y.; Shen, W.; Zhong, Q.; Chen, Q.; He, X.; Baker, J.L.; Xiong, K.; Jin, X.; Wang, J.; Hu, F.; et al. Development of a Bacteriophage Cocktail to Constrain the Emergence of Phage-Resistant. Front. Microbiol. 2020, 11, 327. [CrossRef]

55. Yu, L.; Wang, S.; Guo, Z.; Liu, H.; Sun, D.; Yan, G.; Hu, D.; Du, C.; Feng, X.; Han, W.; et al. A guard-killer phage cocktail effectively lyses the host and inhibits the development of phage-resistant strains of Escherichia coli. Appl. Microbiol. Biotechnol. 2018, 102, 971-983. [CrossRef] [PubMed]

56. Yuan, Y.; Wang, L.; Li, X.; Tan, D.; Cong, C.; Xu, Y. Efficacy of a phage cocktail in controlling phage resistance development in multidrug resistant Acinetobacter baumannii. Virus Res. 2019, 272, 197734. [CrossRef]

57. Rodriguez-Rubio, L.; Martinez, B.; Donovan, D.M.; Rodriguez, A.; Garcia, P. Bacteriophage virion-associated peptidoglycan hydrolases: Potential new enzybiotics. Crit. Rev. Microbiol. 2013, 39, 427-434. [CrossRef] [PubMed]

58. Jacob, F.; Fuerst, C.R. The mechanism of lysis by phage studied with defective lysogenic bacteria. J. Gen. Microbiol. 1958, 18, 518-526. [CrossRef] [PubMed]

59. Cahill, J.; Young, R. Phage Lysis: Multiple Genes for Multiple Barriers. Adv. Virus Res. 2019, 103, 33-70. [CrossRef] [PubMed]

60. Rashel, M.; Uchiyama, J.; Ujihara, T.; Uehara, Y.; Kuramoto, S.; Sugihara, S.; Yagyu, K.-I.; Muraoka, A.; Sugai, M.; Hiramatsu, K.; et al. Efficient elimination of multidrug-resistant Staphylococcus aureus by cloned lysin derived from bacteriophage phi MR11. J. Infect. Dis. 2007, 196, 1237-1247. [CrossRef] [PubMed]

61. Son, J.-S.; Lee, S.-J.; Jun, S.Y.; Yoon, S.J.; Kang, S.H.; Paik, H.R.; Kang, J.O.; Choi, Y.-J. Antibacterial and biofilm removal activity of a podoviridae Staphylococcus aureus bacteriophage SAP-2 and a derived recombinant cell-wall-degrading enzyme. Appl. Microbiol. Biotechnol. 2010, 86, 1439-1449. [CrossRef] [PubMed]

62. Bartell, P.F.; Orr, T.E.; Lam, G.K. Polysaccharide depolymerase associated with bacteriophage infection. J. Bacteriol. 1966, 92, 56-62. [CrossRef] [PubMed]

63. Roach, D.R.; Donovan, D.M. Antimicrobial bacteriophage-derived proteins and therapeutic applications. Bacteriophage 2015, 5, e1062590. [CrossRef]

64. Maciejewska, B.; Olszak, T.; Drulis-Kawa, Z. Applications of bacteriophages versus phage enzymes to combat and cure bacterial infections: An ambitious and also a realistic application? Appl. Microbiol. Biotechnol. 2018, 102, 2563-2581. [CrossRef] [PubMed]

65. Latka, A.; Maciejewska, B.; Majkowska-Skrobek, G.; Briers, Y.; Drulis-Kawa, Z. Bacteriophage-encoded virion-associated enzymes to overcome the carbohydrate barriers during the infection process. Appl. Microbiol. Biotechnol. 2017, 101, 3103-3119. [CrossRef]

66. Comeau, A.M.; Tetart, F.; Trojet, S.N.; Prere, M.F.; Krisch, H.M. Phage-Antibiotic Synergy (PAS): Beta-lactam and quinolone antibiotics stimulate virulent phage growth. PLoS ONE 2007, 2, e799. [CrossRef] [PubMed]

67. Verma, V.; Harjai, K.; Chhibber, S. Structural changes induced by a lytic bacteriophage make ciprofloxacin effective against older biofilm of Klebsiella pneumoniae. Biofouling 2010, 26, 729-737. [CrossRef] 
68. Duc, H.M.; Son, H.M.; Ngan, P.H.; Sato, J.; Masuda, Y.; Honjoh, K.I.; Miyamoto, T. Isolation and application of bacteriophages alone or in combination with nisin against planktonic and biofilm cells of Staphylococcus aureus. Appl. Microbiol. Biotechnol. 2020. [CrossRef]

69. Torres-Barcelo, C.; Hochberg, M.E. Evolutionary Rationale for Phages as Complements of Antibiotics. Trends Microbiol. 2016, 24, 249-256. [CrossRef]

70. Xia, F.; Li, X.; Wang, B.; Gong, P.; Xiao, F.; Yang, M.; Zhang, L.; Song, J.; Hu, L.; Cheng, M.; et al. Combination Therapy of LysGH15 and Apigenin as a New Strategy for Treating Pneumonia Caused by Staphylococcus aureus. Appl. Environ. Microbiol. 2016, 82, 87-94. [CrossRef]

71. Kronheim, S.; Daniel-Ivad, M.; Duan, Z.; Hwang, S.; Wong, A.I.; Mantel, I.; Nodwell, J.R.; Maxwell, K.L. A chemical defence against phage infection. Nature 2018, 564, 283-286. [CrossRef] [PubMed]

72. Abedon, S.T. Phage-Antibiotic Combination Treatments: Antagonistic Impacts of Antibiotics on the Pharmacodynamics of Phage Therapy? Antibiotics 2019, 8, 182. [CrossRef]

73. Segall, A.M.; Roach, D.R.; Strathdee, S.A. Stronger together? Perspectives on phage-antibiotic synergy in clinical applications of phage therapy. Curr. Opin. Microbiol. 2019, 51, 46-50. [CrossRef] [PubMed]

74. Dams, D.; Brøndsted, L.; Drulis-Kawa, Z.; Briers, Y. Engineering of receptor-binding proteins in bacteriophages and phage tail-like bacteriocins. Biochem. Soc. Trans. 2019, 47, 449-460. [CrossRef] [PubMed]

75. Duplessis, M.; Moineau, S. Identification of a genetic determinant responsible for host specificity in Streptococcus thermophilus bacteriophages. Mol. Microbiol. 2001, 41, 325-336. [CrossRef]

76. Mahichi, F.; Synnott, A.J.; Yamamichi, K.; Osada, T.; Tanji, Y. Site-specific recombination of T2 phage using IP008 long tail fiber genes provides a targeted method for expanding host range while retaining lytic activity. FEMS Microbiol. Lett. 2009, 295, 211-217. [CrossRef]

77. Dunne, M.; Rupf, B.; Tala, M.; Qabrati, X.; Ernst, P.; Shen, Y.; Sumrall, E.; Heeb, L.; Plückthun, A.; Loessner, M.J.; et al. Reprogramming Bacteriophage Host Range through Structure-Guided Design of Chimeric Receptor Binding Proteins. Cell Rep. 2019, 29. [CrossRef]

78. Yehl, K.; Lemire, S.; Yang, A.C.; Ando, H.; Mimee, M.; Torres, M.T.; de la Fuente-Nunez, C.; Lu, T.K. Engineering Phage Host-Range and Suppressing Bacterial Resistance through Phage Tail Fiber Mutagenesis. Cell 2019, 179, 459-469.e9. [CrossRef]

79. Westwater, C.; Kasman, L.M.; Schofield, D.A.; Werner, P.A.; Dolan, J.W.; Schmidt, M.G.; Norris, J.S. Use of genetically engineered phage to deliver antimicrobial agents to bacteria: An alternative therapy for treatment of bacterial infections. Antimicrob. Agents Chemother. 2003, 47, 1301-1307. [CrossRef]

80. Yacoby, I.; Bar, H.; Benhar, I. Targeted drug-carrying bacteriophages as antibacterial nanomedicines. Antimicrob. Agents Chemother. 2007, 51, 2156-2163. [CrossRef]

81. Dong, S.; Shi, H.; Zhang, X.; Chen, X.; Cao, D.; Mao, C.; Gao, X.; Wang, L. Difunctional bacteriophage conjugated with photosensitizers for Candida albicans-targeting photodynamic inactivation. Int. J. Nanomed. 2018, 13, 2199-2216. [CrossRef]

82. B Barrangou, R.; Fremaux, C.; Deveau, H.; Richards, M.; Boyaval, P.; Moineau, S.; Romero, D.A.; Horvath, P. CRISPR provides acquired resistance against viruses in prokaryotes. Science 2007, 315, 1709-1712. [CrossRef] [PubMed]

83. Koonin, E.V.; Makarova, K.S.; Zhang, F. Diversity, classification and evolution of CRISPR-Cas systems. Curr. Opin. Microbiol. 2017, 37, 67-78. [CrossRef] [PubMed]

84. Greene, A.C. CRISPR-Based Antibacterials: Transforming Bacterial Defense into Offense. Trends Biotechnol. 2018, 36, 127-130. [CrossRef]

85. Li, Y.; Peng, N. Endogenous CRISPR-Cas System-Based Genome Editing and Antimicrobials: Review and Prospects. Front. Microbiol. 2019, 10, 2471. [CrossRef]

86. Shmakov, S.; Smargon, A.; Scott, D.; Cox, D.; Pyzocha, N.; Yan, W.; Abudayyeh, O.O.; Gootenberg, J.S.; Makarova, K.S.; Wolf, Y.I.; et al. Diversity and evolution of class 2 CRISPR-Cas systems. Nat. Rev. Microbiol. 2017, 15, 169-182. [CrossRef]

87. Yan, W.X.; Hunnewell, P.; Alfonse, L.E.; Carte, J.M.; Keston-Smith, E.; Sothiselvam, S.; Garrity, A.J.; Chong, S.; Makarova, K.S.; Koonin, E.V.; et al. Functionally diverse type V CRISPR-Cas systems. Science 2019, 363, 88-91. [CrossRef] [PubMed]

88. Seed, K.D.; Lazinski, D.W.; Calderwood, S.B.; Camilli, A. A bacteriophage encodes its own CRISPR/Cas adaptive response to evade host innate immunity. Nature 2013, 494, 489-491. [CrossRef] 
89. Levasseur, A.; Bekliz, M.; Chabriere, E.; Pontarotti, P.; La Scola, B.; Raoult, D. MIMIVIRE is a defence system in mimivirus that confers resistance to virophage. Nature 2016, 531, 249-252. [CrossRef]

90. Pawluk, A.; Staals, R.H.J.; Taylor, C.; Watson, B.N.J.; Saha, S.; Fineran, P.C.; Maxwell, K.L.; Davidson, A.R. Inactivation of CRISPR-Cas systems by anti-CRISPR proteins in diverse bacterial species. Nat. Microbiol. 2016, 1, 16085. [CrossRef]

91. Yosef, I.; Manor, M.; Kiro, R.; Qimron, U. Temperate and lytic bacteriophages programmed to sensitize and kill antibiotic-resistant bacteria. Proc. Natl. Acad. Sci. USA 2015, 112, 7267-7272. [CrossRef] [PubMed]

92. Dy, R.L.; Richter, C.; Salmond, G.P.; Fineran, P.C. Remarkable Mechanisms in Microbes to Resist Phage Infections. Annu. Rev. Virol. 2014, 1, 307-331. [CrossRef] [PubMed]

93. Caflisch, K.M.; Suh, G.A.; Patel, R. Biological challenges of phage therapy and proposed solutions: A literature review. Expert Rev. Anti Infect. 2019, 17, 1011-1041. [CrossRef]

94. Silpe, J.E.; Bassler, B.L. A Host-Produced Quorum-Sensing Autoinducer Controls a Phage Lysis-Lysogeny Decision. Cell 2019, 176, 268-280.e13. [CrossRef]

95. Colom, J.; Cano-Sarabia, M.; Otero, J.; Cortes, P.; Maspoch, D.; Llagostera, M. Liposome-Encapsulated Bacteriophages for Enhanced Oral Phage Therapy against Salmonella spp. Appl. Environ. Microbiol. 2015, 81, 4841-4849. [CrossRef]

96. Nieth, A.; Verseux, C.; Barnert, S.; Suss, R.; Romer, W. A first step toward liposome-mediated intracellular bacteriophage therapy. Expert Opin. Drug Deliv. 2015, 12, 1411-1424. [CrossRef] [PubMed]

97. Penades, J.R.; Chen, J.; Quiles-Puchalt, N.; Carpena, N.; Novick, R.P. Bacteriophage-mediated spread of bacterial virulence genes. Curr. Opin. Microbiol. 2015, 23, 171-178. [CrossRef]

98. Nau, R.; Eiffert, H. Modulation of release of proinflammatory bacterial compounds by antibacterials: Potential impact on course of inflammation and outcome in sepsis and meningitis. Clin. Microbiol. Rev. 2002, 15, 95-110. [CrossRef]

99. Tetz, G.V.; Ruggles, K.V.; Zhou, H.; Heguy, A.; Tsirigos, A.; Tetz, V. Bacteriophages as potential new mammalian pathogens. Sci. Rep. 2017, 7, 7043. [CrossRef]

100. Van Belleghem, J.D.; Clement, F.; Merabishvili, M.; Lavigne, R.; Vaneechoutte, M. Pro- and anti-inflammatory responses of peripheral blood mononuclear cells induced by Staphylococcus aureus and Pseudomonas aeruginosa phages. Sci. Rep. 2017, 7, 8004. [CrossRef]

101. Payne, R.J.; Phil, D.; Jansen, V.A. Phage therapy: The peculiar kinetics of self-replicating pharmaceuticals. Clin. Pharm. 2000, 68, 225-230. [CrossRef] [PubMed]

102. Fauconnier, A. Phage Therapy Regulation: From Night to Dawn. Viruses 2019, 11, 352. [CrossRef] [PubMed]

Publisher's Note: MDPI stays neutral with regard to jurisdictional claims in published maps and institutional affiliations.

(C) 2020 by the authors. Licensee MDPI, Basel, Switzerland. This article is an open access article distributed under the terms and conditions of the Creative Commons Attribution (CC BY) license (http://creativecommons.org/licenses/by/4.0/). 